\title{
Miyuan, (re)imaginings of the Japanese legacy, and the making of postcolonial discourse in 1990s Taiwan
}

\author{
Coraline Jortay ${ }^{1}$
}

\begin{abstract}
This paper analyzes the early phases of reception of Li Ang's 1991 novel Miyuan (The Lost Garden) in newspapers and literary magazines in Taiwan, and explores its articulations with the early localization of postcolonial theory. Indeed, while Miyuan is generally regarded as a token of 228 literature, my findings indicate that the initial reception of the novel was not so much concerned with 228 or the White Terror, but rather with unpacking the book's (re)imaginings of the Japanese colonial heritage, and the continuities and discontinuities in shifting from Japanese to KMT regimes in areas as varied as the school system, ethnicity, discrimination, language use, or even gardening. Such discussions were significant because they were among the first readings of local literary works happening alongside early translations of postcolonial thought in Chinese, and introduction thereof onto the literary scene in Taiwan. They prefigured the rise of the "1992 debate", usually posited as the beginning of the debate on postcoloniality in Taiwan, and contribute to discussions on literary discourse as co-constitutive of memory work in the 1990s.
\end{abstract}

Keywords: Li Ang, reception, postcolonial discourse, memory, Miyuan

\begin{abstract}
Résumé
Cet article analyse la réception dans les journaux et les magazines littéraires du roman Miyuan (Le jardin des égarements) publié par Li Ang en 1991, analysant la manière dont celle-ci s'articule avec les débuts de la localisation des théories postcoloniales à Taiwan. En effet, si Miyuan est généralement considéré comme une œuvre-clef de la littérature dite « du 28 février », notre analyse tend à montrer que la phase initiale de réception dans la presse périodique ne s'est pas tant intéressée au roman dans son rapport aux événements du 28 février ni à la Terreur blanche, mais plutôt aux (ré)imaginations de l'héritage colonial japonais déployées par le roman, ainsi qu'aux continuités et discontinuités entre le régime japonais et celui du Kuomintang dans des domaines aussi variés que le système scolaire, les questions d'ethnicité, de discrimination, de langue ou encore de jardinage. Ces discussions sont importantes dans la mesure où elles ont constitué l'une des premières lectures d'une œuvre littéraire locale aux côtés des premières traductions des théories postcoloniales en chinois et de leur introduction sur la scène littéraire taïwanaise. En ce sens, elles préfigurent le plus large « débat de 1992 » auquel on fait généralement remonter le début des débats postcoloniaux à Taiwan, et contribuent à délimiter les rapports entre discours littéraire et travail de mémoire dans les années quatre-vingt dix.
\end{abstract}

Mots-clefs : Li Ang, réception, discours postcolonial, mémoire, Miyuan

\footnotetext{
1 Jortay, Coraline, Aspirante F.R.S.-FNRS, Université Libre de Bruxelles (ULB), EASt, Philixte, Striges, coraline.jortay@ulb.ac.be, Maison des Sciences Humaines de l’ULB, 50, avenue Franklin Roosevelt, CP 129/08 1050 Bruxelles, Belgique.
} 


\section{Miyuan, (re)imaginings of the Japanese legacy, and the making of postcolonial discourse in 1990s Taiwan ${ }^{2}$}

\section{Introduction}

When I first arrived in Taipei in the spring of 2017 to gather sources related to Li Ang's Miyuan ${ }^{3}$ (迷園) as part of a larger research project on reported speech and interior monologue in sinophone women writers' work, I was surprised to get an overall negative reaction from scholars, librarians, and bookshop owners alike : why such a choice while there where so many interesting new writers on the literary scene? And above all, why Miyuan, which had been debated so much in the 1990s already? Could I not find a more original research topic? My puzzlement led me to take a closer look at the original reception of Miyuan in newspapers and literary magazines for that time period. Gradually, I realised that, as much as the remarks above were true, the 1990s debates on Miynan also captured a very particular moment of Taiwanese history when, directly after the lifting of the martial law, society grappled to make sense of its colonial heritage, of the past three decades of martial law and, at its core, of the dramatic transition years that the 1930s-1950s had been. Rising together with the introduction of postcolonial thought in Taiwan, they prefigured in many ways the advent of the larger "1992 debate" on postcoloniality, a fact which seems to have been overlooked by previous scholarship. Meanwhile, Li Ang herself acknowledged the tremendous influence that postcolonial critics such as Edward Saïd and Homi Bhabha had on her works and did not hesitate, during an official visit to France, to call out the aftertaste of racism and colonialism she felt during a visit to local museums ${ }^{4}$.

Weaving together the reception of Miyuan in a dozen literary magazines and newspapers for the period 1990-1994, this paper explores the consecutive phases of reception of the novel: which interpretations were privileged at what times? Which did not register as much with readers, or did not register until later years? How do these reception phases speak to the broader debates occurring in

\footnotetext{
${ }^{2}$ I wish to acknowledge the support of the Taiwan Fellowship in enabling the research trip to the National Central Library in Taipei that allowed me to gather sources from the periodical press critical for such a study of reception.

${ }^{3}$ Li Ang (李昂), The Lost Garden (Miyuan 迷園), Taipei: self-published, 1991.

${ }^{4} \mathrm{Li}$ Ang, «La modernisation et l'occidentalisation à Taiwan », trad. Sandrine Marchand, Ecrire au présent, débats littéraires franco-chinois, Paris : Éditions de la Maison des sciences de l'homme, 2004, p. 277-283.
} 
Taiwan in the 1990s? More specifically, I highlight how reception has emphasized the depiction of the Japanese colonial period in general, and the continuities and discontinuities between Japanese and KMT periods that marked the 1930-50s in particular, drawing on elements from the second narrative thread of the novel where the memories and flashbacks are set.

Doing so allows me to probe how literary debates on Miyuan could effectively function as a feedback loop that drew on discourses about memory and colonialism prevalent in Taiwan at the time, but also influenced them. Indeed, as Neumann points out ${ }^{6}$ in her discussion of Nünning's "fictions of memory", "literature represents a 'reintegrative interdiscourse' [...] interwoven with other systems such as psychology, historiography, law or religion, and which draws on contents and concepts of memory that already circulate in a culture." In Taiwan, the early nineties constituted a sharp turning point from fourty years of official KMT narrative of memory that involved "telling a shared past (the 5000-year Chinese history), a shared present (defeated by the Chinese communists and temporary residence in Taiwan), and a shared future (recovering mainland China)" ${ }^{\text {" }}$. As projects concerned with local memory (the February 28 Incident) or local language were advocated by the newly founded Democratic Progressive Party (DPP) before being progressively set into motion by the government throughout the next decade, novels dealing with "fictions of memory" (chiefly about 228 and the White Terror, but also about the Japanese period, or earlier history of the island) saw the light en masse. In this context, analyzing critical reception can help illuminate the "stories that individuals or cultures tell about their past to answer the question "who am I?", or, collectively, "who are we?"” even as they "turn out to be an imaginative (re)construction of the past in response to current needs.".".

\section{Corpus and scope of analysis}

While Miyuan had a lasting impact on the local and international literary scene ${ }^{10}$ and, three decades on, continues to generate a wealth of scholarship, this paper constitutes the first study to date

\footnotetext{
${ }^{5}$ Miyuan runs in two narrative threads: the first, set in the 1970-80s, follows Zhu Yinhong as an adult in her relationship with Lin Xigeng, a real estate tycoon; the second follows her childhood memories in the early 1950s, linking back to the past of her father in the 1930s.

${ }^{6}$ Neumann, Birgit. The Literary Representation of Memory. In Cultural Memory Studies: An International and Interdisciplinary Handbook, 333-43, 2008.

${ }^{7}$ Nünning, Ansgar, ed. Fictions of Memory. Special issue of the Journal for the Study of British Cultures, 2003, 10 , no. 1.

${ }^{8}$ Yeh, Hsin-Yi. Telling a Shared Past, Present, and Future to Invent Nationality: The Commemorative Narrative of Chinese-Ness from 1949 through 1987 in Taiwan. Memory Studies, 2018, 11, no. 2: 172-90, p. 175.

${ }^{9}$ Neumann 2008, p. 334

${ }^{10}$ With translations in Czech, English, French, Japanese, and Korean.
} 
to conduct a specific analysis of its reception in literary magazines and newspapers. After a preliminary investigation for the period starting from August 1990 (beginning of the serialization of Miyuan in the China Times) to July 1997 (when the press attention shifted to the "Beigang incense burner" controversy $^{11}$ ), more systematic scrutiny was applied to the period March 1991-February 1994, where the bulk of reception occurred ${ }^{12}$. Periodicals reviewed include the three main general-news national newspapers ${ }^{13}$, i.e. the United Daily News (or for our purposes its literary supplement Lianhe Fukan 聯合 副刊), the Liberty Times (Ziyou shibao 自由時報), and the China Times (Zhongguo Shibao 中國時報) where Miyuan was serialized between August 18, 1990 and March 11, 1991 in 189 installments before being published in book form in March 1991. Two more daily publications were considered: the tabloid Minsheng Bao (民生報) affiliated with United Daily News, and the Zhongyang Ribao (中央日報), the former official newspaper of the KMT. Taken altogether, they represent the major print press outlets across the political spectrum ${ }^{14}$.

In addition, I reviewed literary magazines including Unitas: A Literary Monthly (Lianhe wenxue 聯合文學), Contemporary monthly (Dangdai 當代), Taiwan Wenyi (台灣文藝), Wenxun (文訊), and Wenxue Taiwan (文學台灣). My analysis has privileged literary magazines aimed at the general public widely available in bookshops. More academically-focused publication, such as the Chung-Wai Literary Monthly (Zhongwai wenxue 中外文學), have not been included, especially as the debates taking place in their columns with regards to postcolonialism in the mid-90s have been well described ${ }^{15}$.

Newspapers were reviewed in digitized version using the Taiwan News Smartweb (Taiwan Xinwen Zhuibuiwang 台灣新聞智慧網) database and the National Newspapers Information System (Quan guo baozhi

\footnotetext{
${ }^{11}$ Named after her collection of stories Everyone Sticks His Incense in the Beigang Incense Burner (Beigang xianglu renren cha 北 港香爐人人插) published in September 1997, which was read as frontal attack against a well-known female political figure and led to a widespread media battle (a keyword search in the China Times alone turns out more than a hundred and fifty articles for July-November 1997).

${ }^{12}$ Indeed, Miyuan did not garner much critical review before its publication in book form, neither after public attention turned to Li Ang Shuo Qing (李昂說情) in March 1994.

${ }^{13}$ Lee, Ya-Ching. Effects of Market Competition on Taiwan Newspaper Diversity, Journal of Media Economics, 2007, 20:2, 139-156, pp. 140-141.

${ }^{14}$ Rawnsley, Gary \& Ming-Yeh. Regime transition and the media in Taiwan, Democratization, 1998, 5:2, pp. $106-124$.

15 See: Liou, Liang-Ya. Taiwan's Post-Colonial and Queer Discourses in the 1990s. In Comparatizing Taiwan, ed. Shu-mei Shih and Ping-hui Liao (New York: Routledge, 2015), 259-77; Chen, Chun-yen. Being-in-common in postcolonial Taiwan. Interventions, 2012, 14:3, 443-461; Liao, Ping-Hui. Postcolonial studies in Taiwan: Issues in critical debates. Postcolonial Studies, 1999, 2:2, 199-211.
} 
zixun xitong 全國報紙資訊系統). Literary magazines were reviewed in paper form, as digitization is still partial (Lianhe wenxue, Dangdai) or non-existent (Wenxun, Wenxue Taiwan). As the chosen method and timeframe allowed me to gauge the immediate reaction of society and literary circles to the novel, I paid special attention to the surrounding articles and paratext, in search for themes that seemed to appear recurringly together with discussions of Miyman. My choice to refer to some of the criticism articles on Miyuan the Miyuan debate, rather than as a series of disconnected pieces, is informed by the fact that reception articles frequently referenced each other across publication outlets, or involved letters to the editors and "response articles"16.

\section{Missed reception: Miyuan as 228 literature}

Over the decades, the February $28^{\text {th }}$ Incident as an identity-shaping watershed event has been widely studied, especially as it relates to the relationship between "the "facts" of history and the process of their performative and narrative construction ${ }^{17}$ ". In the literary realm, it has generated a wide array of novels and short stories, as novelists have been looking to confront and revisit painful memories, reflect on its impact on the island's fate, and embark readers of younger generations on the path to remembrance. Although some earlier literary works already hint at the event, the majority were published in the wake of the lifting of the martial law in 1987, with - for instance - Lin Yaode's (林 燿德) 1947 Formosa Lily (Yijiu si qi gaosha baibe 一四九七高砂百合) in 1989, or Chen Ye’s (陳燁) Muddy River (Nibe 泥河, 1990). Since then, the enormous body of literature published on the subject has come to constitute its own literary category of “February 28 literature" (Er er ba wenxue 二二八文 學), with a wide array of styles from modernism to postmodernism, and from realism to magic realism ${ }^{18}$.

\footnotetext{
${ }^{16}$ For instance, the following piece published in Dangdai involves cross-references to four different reception articles about Miyuan published across 1991-1992 in different outlets: Jin Hengjie (金恒杰), The new golden aristocracy: reevaluating Miyuan, between packaging and commodities (Huangjin xin guizu - baozhuang yu shangpin zhijian - zai ping Miyuan: 黃金新貴族--包裝與商品之間--再評《迷園》), Dangdai, March 1992, pp. 130-147.

${ }^{17}$ Edmonson, Robert. The February 28 incident and national identity. Memories of the future: national identity issues and the search for a new Taiwan, ed. S. Corcuff (New York: Routledge, 2002), 25-46, p. 25.

${ }^{18}$ Berry, Michael. A History of Pain: Trauma in Modern Chinese Literature and Film (New York: Columbia University Press, 2011 [2008]), p. 212.
} 
Among those novelists, Li Ang (李昂, 1952-present) has delved into the topic extensively ${ }^{19}$ from various perspectives (gendered, historical, biographical) in The Masquerade for a Blood Sacrifice (Caizhuang xueji 彩妝血祭, 1997), Autobiography : A Novel (Ziz̧huan no xiaoshuo 自傳の小說, 2000) and, first and foremost, Miyuan (迷園, 1991). Among the first full-fledged novels written just after the lifting of the martial law to re-create the White Terror period, Miyuan has since become a token of 228 literature that has been described as "alternative takes on February 28 history precisely [intended] as a way of correcting political bias ${ }^{20}$ '.

However, the February 28 Incident and the White Terror do not seem to have been a major axis of reception by the public and critics in 1990-91, although February 28 fiction had been anthologized as soon as $1989^{21}$. Only a couple articles referring to it can be found in the later stages of reception in 1992 and 1993, but either only in passing by Li Ang herself $\mathrm{f}^{22}$ or in the wider context of Li Ang's self-designated mission to write down Taiwan history and her upcoming biography of Shih Ming-te ${ }^{23}$. Such a reception is surprising given the dozens of commemorative activities that happened in the same timeframe as the writing of Miyuan (1987-1990): street marches organized by the DPP, commemorative concerts, and general discontent that led to the building of the memorial monument in Chiayi in 1989 and later to the Executive Yuan setting up an investigation committee ${ }^{24}$. It also appears markedly different from the reception of Li Ang's Ziæhuan no xiaoshuo, which would be abundantly discussed in the context of 228 even before the publication of the book and tied explicitly to 228 in the titles of literary reviews. Of course, Miynan was first self-edited and its pressrun limited

\footnotetext{
${ }_{19} \mathrm{Wu}$, Chia-rong. Supernatural Sinophone Taiwan and Beyond. (Amherst: Cambria Press, 2016); Sung, Mei-hwa. Writing Women's Literary History: Gender Discourse and Women's Literature in Taiwan. Gender, Discourse and the Self in Literature: Issues in Mainland China, Taiwan and Hong Kong, ed. Kwok-kan Tam (Hong Kong: The Chinese University Press, 2010), 17192.

${ }^{20}$ Hillenbrand, Margaret. Trauma and the Politics of Identity: Form and Function in Fictional Narratives of the February 28th Incident. Modern Chinese Literature and Culture, 2005, 17, no. 2, 49-89, p. 56.

${ }^{21}$ Lin Shuangbu (林雙不), A selection of Taiwan's February 28th fiction (Er er ba Taiwan xiaoshuo xuan二二八臺灣小說 選), Taipei: Zili wanbao wenhua, 1989.

${ }^{22}$ Li Ang (李昂), From Flower Season to the Lost Garden (Huaji dao Miyuan 《花季》到《迷園》), China Times, July 15,1993 , p. 27.

${ }^{23}$ Zhang Juanfen (張娟芬), Li Ang is writing a biography of Shih Ming-te the woman's way (Li Ang yi nüxing fangshi wei Shi Mingde xie zhuan 李昂以「女性方式」為施明德寫傳), China Times, August 28, 1992, p. 31.

${ }^{24}$ Shih, Cheng-feng, and Mumin Chen. Taiwanese identity and the memories of 2-28: a case for political reconciliation. Asian Perspective 2010, 34, no. 4: 85-113.
} 
for political reasons ${ }^{25}$, which might have contributed to a more limited diffusion, but it nevertheless managed to spark a large debate on (post)coloniality, as will be discussed in the following section.

\section{Early reception}

In early reviews published in the Minsheng Bao, Lianhe Wenxue and $W$ enxun from June to December 1991, Miyuan was first discussed in terms of nativization ${ }^{26}$ (bentubua 本土化), associated with discussions of the significance of the pirate ancestry of the novel's main protagonist in relation to her spirit of independence. A second common thread of early reception, although it only starts after publication of Miyuan in book form (since passages that deemed offensive had been excised from the newspaper release ${ }^{27}$ ), is the objectification of the body as it relates to consumerism ${ }^{28}$, sex and power. Accusations of the book being of "bad taste" for the seriousness its subject deserves notwithstanding, critics examined the prevalent commodification of contemporary society and gender relations, which they tied to the locus of the garden, a metaphor for Taiwanese culture, as the main protagonist sells herself into marrying a rich tycoon to restore the garden and remove its Chinese influences ${ }^{29}$. Interestingly, one of these reviews was published as part of a special issue on sex and literature largely devoted to discussing cultural taboos, and Foucault's History of Sexuality. This early phase of criticism also echoes the concerns of early postcolonial critic Liao Chaoyang 廖朝陽, who, analyzing Lim Giong’s (林強) Marching Forward (Wang qian zou 向前走, 1990) around the same time period, argues that the "cultural hybridity developed in popular culture [is] a result of the objectification of Taiwanese culture under KMT rule" and sees the latter as a byproduct of Chinese nationalism that has historically repressed its memories and historical experiences ${ }^{30}$.

\footnotetext{
${ }^{25} \mathrm{Li}$ Jin(李進), Reprint of Li Ang’s Miyuan to be published (Li Ang Miyuan xinban chongfan shushi李昂迷園新版重返書 市), United Daily News Weekly Literary Supplement, June 29 1998, p. 48.

${ }^{26}$ See for instance: Lü Zhenghui (呂正惠), The double [narrative] thread and puzzlement of Miyuan (Miyuan de shuangxian yu kungan《迷園》的雙線與困感), Minsheng Bao, June 16, 1991, p. 26.

${ }^{27}$ See: Li Ang (李昂), Hello Mister Li Ang (Li Ang xiangsheng ni hao 先生你好), Lianhe Wenxue, n 83 , September 1991. ${ }^{28}$ Wenxun, Miyuan, by Li Ang (Miyuan/ Li Ang zhu 迷園/李昂著), Wenxun, n²28, May 1991, p. 83.

${ }^{29}$ Lü Zhenghui (呂正惠), Gender relations in Miyuan and the real face of Taiwan mercantilism (Miyuan de liang xing guanxi yu Taiwan qiyezhu de zhenmao 《迷園》的兩性關係與臺灣企業主的真貌), Lianhe Wenxue, September 1991, n83: 161165, p. 161; Huang Yuxiu (黃毓秀), Sadomasochistic women? On Li Ang's Miyuan (Bei nüepi de nüren? Tan Li Ang xiaoshuo Miyuan 被虐癖的女人? --談李昂小說《迷園》), Liberty Times supplement, December 19, 1992, p. 25. ${ }^{30}$ Liou 2015.
} 
In the context of Miyuan, questions of decadence, memory and objectification are juxtaposed in Taiwan's fast-paced, luxurious and decadent society of the 1970s and 80s, with its swirl of business dinners and onerous watches, embodied by the tycoon Lin Xigeng, with the decadency of Yinghong's father who drains the family fortune in buying many high-end cameras and luxury cars, as he has to spend his life cloistered in the garden, forever under suspicion after he was arrested in the February 28th incident. Discussions of these themes of decadence - of the garden, of gender relations, of memory - can be found in later reception articles throughout the early nineties ${ }^{31}$, even after articles mainly dealing with Japanese heritage and coloniality take center stage.

\section{Miyuan and the making of the postcolonial debate}

If the early debates above did not bear the name postcolonial, anecdotal evidence of editorial choices $^{32}$ show that they were often already juxtaposed directly to articles that interrogate the double Chinese/Japanese heritage and, together, could be read as attempts to articulate identities beyond "both/and" and "neither/nor" that resound with Bhabha's notion of hybridity. The first occurrence of the term postcolonial (bouzhimin 後殖民) in a literary magazine in Taiwan, however, can be traced back to the December 1991 issue of Wenxue Taiwan ${ }^{33}$. However, as Chen Chun-yen posits, Chen Fangmin's use of the term then was "nothing more than a temporal marker" and not yet an analytical framework ${ }^{34}$.

According to scientific literature, the postcolonial debate rose to prominence in literary and cultural studies circles in Taiwan after Chiu Kuei-fen (邱貴芬) delivered her paper Discovering Taiwan (Faxian Taiwan 發現臺灣) at the sixteenth annual ROC Comparative Literature conference in May 1992. The ensuing debate between herself and Liao Chao-yang in the columns of Chung-wai Literary Monthly is generally taken as the first instance of literary postcolonial debate in Taiwan and focused on language "as a medium of knowledge and power" and postcolonialism as an "historical stage of

\footnotetext{
${ }^{31}$ Huang Yuxiu, 1992 ; Lin Daiman (林黛嫚), Women writers on women writers: Liao Huiying vs. Li Ang vs. Cao Youfang (Nü zuojia tan nü zuojia: Liao Huiying VS Li Ang VS Cao Youfang 女作家談女作家廖輝英 VS 李昂 VS 曹又方), Zhongyang Ribao supplement, September 2 and 2, 1991, p. 16.

${ }^{32}$ For instance, Lin Shuifu (林水福), Lu Xun in Japan (Lu Xun zai Riben 魯迅在日本), Lianhe Wenxue, n83, September 1991, p. 136- 140 is immediately juxtaposed with two different articles on Li Ang and Miyuan.

${ }^{33}$ Chen Fangming (陳芳明), Raising the banner of the 90s - An opening statement for Wenxue Taiwan (Chengqi 90 niandai de qizhi 撐起九 $\bigcirc$ 年代的旗幟 — 《文學台灣》發刊詞), Wenxue Taiwan, December 25, 1991, pp. 7-12.

${ }^{34}$ Chen 2012, p. 448.
} 
collective memory retrieval and of nation rebuilding, ${ }^{35}$. Debates further swelled, with many special issues of collective memory and the construction of history ${ }^{36}$, and continued well into 1995, raising further questions regarding the position of Taiwan literature within/outside Chinese literature, imperialism, as well as questioning between "gaps and lapses between literary discourse and social practices $^{37}$, Literary works frequently discussed as part of the literary canon in formation included Wu He's Remains of Life, Wu Zhuoliu's Orphan of Asia, and more.

However, there seems to be a missing piece in this discussion: the very first debate on postcoloniality taking place in the pages of a literary magazine in Taiwan was actually published earlier, as the March 1992 issue of Dangdai, under the title A special issue on postcolonial discourse (Hourhimin lunshu zhuanji 後殖民論述專輯). Alongside various translations of Western articles dealing with race and colonialism $^{38}$, it prominently features interview of Homi Bhabha conducted by Liao Ping-hui (廖炳 惠) and discussed the importance of Franz Fanon for probing cultural ambivalence, the complexity of the colonizer-colonized relationship ${ }^{39}$, and the differences between postmodernism and postcolonial theory - one theme that would be taken up again in Chen Fangmin's classic piece ${ }^{40}$ which uses "recolonized era" to replace "postwar era" as a way of describing post-1945 Taiwanese society and its literature. As part of the special issue, an article on Miyman operates a sharp turn in the reception of the novel, sparking a debate on the book's representations of the 1930-50s and colonial legacy that went on for several months (issues $n^{\circ} 71$ through 74) with responses pieces, letters to the editors, and even excerpts from Li Ang's handwritten book manuscript being published to check for accuracy.

As such, Miyuan could be viewed as part of the constituent texts through which the postcolonial debate entered Taiwan: its reception would go on to engage with the same themes of memory retrieval, cultural ambivalence, the complexity of relations between colonizer and colonized,

\footnotetext{
35 Liao 1999, p. 201.

36 See for instance the November 1993 issue of Dangdai. Wang Mingke (王明珂), Collective memory and ethnic identity (Jiti lishi jiyi yu zuqun rentong 集體歷史記憶與族群認同), Dangdai, n91, November 1993.

${ }^{37}$ Liao 1999, p. 206.

${ }^{38}$ For example, a translation of Mark Reid's Dialogic Modes of Representing Africa(s) which explores black womanist films as a corrective measure to the absence of discussion of ethnicity in feminist studies.

${ }^{39}$ Liao Ping-hui (廖炳惠), Postcolonial and Postmodern - An interview with Homi K. Bhabha (Houzhimin yu houxiandai - Homi K. Bhabha de fangtan 後殖民與後現代-Homi K. Bhabha 的訪談), Dangdai, March 1993, nº71, pp. $20-25$.

${ }^{40}$ Chen Fangming (陳芳明), Postmodern or Postcolonial? An Inquiry into Postwar Taiwanese Literary History (Houxiandai buo bouzhimin: zhanhou Taiwan wenxueshi de yi ge jieshi後現代或後殖民: 戰後臺灣文學史的一個解釋), 《後殖民臺灣: 文 學史論及其周邊》。Taipei : Maitian, 2000), pp. 23-46
} 
that would become staples of the larger debates on postcoloniality. More specifically, they highlighted the continuities and discontinuities between the Japanese and KMT periods. Indeed, to quote from Edmonson, in "many significant ways, the Nationalists were unable to distance themselves from the Japanese who had ruled before them. They moved into Japanese residences, filled the most important administrative posts, replaced the Japanese as the police force, nationalized the largest industries previously owned by the Japanese, and imposed Mandarin Chinese, a foreign language to the Taiwanese, as the national dialect. Portraits of the Japanese emperor in public schools and offices were replaced by pictures of Sun Yat-sen and Chiang Kai-shek as the new objects of mandatory ritualized state-worship $^{41}$ ". Debates related to the second phase of reception of Miyuan questioned elements that were inherited from the Japanese and then replicated by the KMT government, and discussed their historical accuracy, or lack thereof, in the novel. Did these elements really first appear under the Japanese regime? How were they implemented? What changed when the Kuomintang took over? What stayed the same?

\subsubsection{School children, haircuts, and embodied coloniality}

A first characteristic of this phase was a marked interest for the depictions of the school system in Taiwan under the Japanese colonization, blown up from a short passage of Miyuan where the main protagonist's father mentions having had Japanese pupils in his class as a child. This detail sparked a debate on the extent of segregation between Japanese and Taiwanese pupils, before and after the advent of the Kominka. Indeed, colonial Taiwan was characterized by a double school system where “children of Japanese colonist settlers and economic and military personnel attended shōgakekō primary schools, and Taiwanese children were educated in kögakkeō common schools ${ }^{42}$ ". As those issues were discussed in relation to colonial policy and feelings of entitlement and ethnic superiority, attention then turned to what became after the KMT takeover: how were Taiwanese children treated in school? Was the distinction between middle school and high school introduced by the KMT to reflect the American school system, or did schools under Japanese rule already have this distinction? And why would the KMT decide to continue to impose the colonial o-kappa haircut on elementary school children? Overlapping concerns regarding the colonial period and the school system would be

\footnotetext{
${ }^{41}$ Edmonson 2002, p. 27.

${ }^{42}$ Scruggs, Bert. Translingual Narration: Colonial and Postcolonial Taiwanese Fiction and Film (Honolulu: University of Hawai'i Press, 2015), p. 153.
} 
recurring throughout the 90 s, with a two-way process of literary debates overflowing towards public society, before generating a new set of literary debates - as exemplified by Liao on the 1997 debates on junior high school history textbooks which then morphed into "another battle in the literary supplement section of United Daily, blatantly denouncing the Kominka literature from Taiwan's Japanese period ${ }^{43}$ ".

\subsubsection{Language and dates as resistance}

The use of Japanese language as an act of resistance was generally acknowledged by critics. In the novel, after being arrested by the KMT, the father is to spend the rest of his life in the "Chinese Garden”, a subtext relying on 菡 and 漢 being quasi-homophones that equates 菡園 hanyuan (the Lotus Garden) to 漢園 hanyuan (the Chinese garden) ${ }^{44}$. However, he manages to regain agency from his confinement by foregoing Chinese culture and making Japanese the official language of his household, educating his children solely in Japanese. Although the fact that the father would curse in Japanese came as a shock to certain critics, the use of kanji and Japanese names, mainly embedded in dialogues or people's names, was also noted to work as temporal marker: while the Japanese surrendering and leaving Taiwan is totally left out of the novel, the allusion to Yinhong's playmates having to revert back to their Chinese name works effectively as temporal signalling.

As Miyuan moves away from precise temporal markers of historical time, the only two precise years provided in the novel, come crashing into one another, as the rest of temporality is either constructed relatively to other elements, or merely hinted at. The first of the two dates given is 1894 , a recurring motif throughout the novel, with no less than 26 occurrences of 甲午戰爭 (Jiawn zhanzheng, the First Sino-Japanese war) that come back again and again as the motto of the novel. The second, 1952, situates the opening of the novel. Such construction is significant because 1952 marks the signature of Treaty of Taipei (Taibei heyue 台北和約 or zhongri heping tiaoyue 中日和平條約), the formal end to the Second Sino-Japanese War. Their overarching prevalence as the only two historical markers

\footnotetext{
43 Liao 1999, p. 207.

${ }^{44}$ Further academic scrutiny of this subtext can be found in: Lin Fangmei (林芳玫), An analysis of Miyuan: the paradox between gender and national identities (Miyuan jiexi - xingbie rentong yu guozu rentong de diaogui 《迷園》解析--性 別認同與國族認同的韦詭), Gender discourse and Taiwan fiction (Xingbie lunshu yu Taiwan xiaoshuo 性別論述與臺灣小說), ed. Mei Jialing(梅家玲), Taipei: Maitian, 2000, pp. 145-72.
} 
in the novel work effectively to equate the Japanese rule and the KMT rule and call out to the symbolic importance of Shimonoseki Treaty for pro-independence activists and discourse on Taiwanese identity in the 1990s - as exemplified with the 1995 Shimonoseki commemorative march heralding the slogan "Farewell to China," that led the pro-unification side to retaliate a couple days later with a counterprotest under the banner "I am Chinese ${ }^{45}$ ". Similar symbolic use of colonial era dates and calendars as acts of protest against the Nationalist government can also be found in the 1994 film $A$ Borrowed Life (Duosang 多桑) where the narrator's father refers to the colonial period whenever asked about his age ${ }^{46}$.

\subsubsection{Transplanted identities}

Another subject of contention in the reception debates was the depiction of plants in Miyuan,

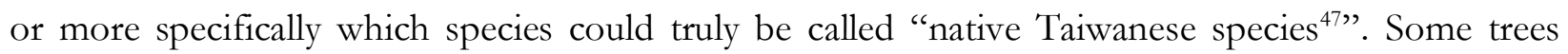
described in the novel as native, such as the flamboyant tree or the coral bean tree, were despised on the grounds of being brought to Taiwan under Japanese colonization ${ }^{48}$. It was argued that others, such as the star fruit tree were actually native to Mainland China, and had been introduced to Taiwan in the beginning of the KMT regime. As such, the argument ran, "at least from botanical point of view, [Taiwan] still lives to some extent in the shadows of Mainland China ${ }^{49}$ ". This prompted a response article from Li Ang herself, who argued that such vision was only good for "narrow proponents of nativism", while Taiwan itself actually was the result of the sum of the mixed, consecutive influences of Holland, Spain, Japan, and China ${ }^{50}$. What the books opposes, she said, is the "blind copying of the Suzhou gardens model, of the Chinese garden model", but that "does not mean that we have to cut down every tree species that's not one hundred percent indigenous to Taiwan", because "going down that route, not even the aborigines would be truly Taiwanese”.

\subsection{Questions left in the shade}

\footnotetext{
${ }^{45}$ Corcuff, Stéphane. Introduction: Taiwan, A Laboratory of Identities. Memories of the Future: National Identity Issues and the Search for a New Taiwan (New York: Routledge, 2002), p. xiii.

${ }^{46}$ Scruggs 2015, p. 20.

${ }^{47}$ Indeed, one plot line of Miyuan follows the main protagonist who attempts to 'nativize' the garden by removing flowers and tree species seen as "non-Taiwanese" to replace them with "Taiwanese species".

${ }^{48}$ Cheng Feng (程風), I'd like to pluck them out - on Miyuan's plants (Wo xiang bacuo le - shuo Miyuan zhong de huamu 我想拔錯了一說《迷園》中的花木), Dangdai, nº73, May 1992, pp. 139-141.

49 Ibid p. 140.

${ }^{50} \mathrm{Li}$ Ang (李昂), An explanation to the explanation: double response regarding Miyuan's plants（Shuoming de shuoming, jianda 說明的說明, 兼答迷園中的花木）, Dangdai, n74, June 1992, pp. 148-149.
} 
The above is one of the few instances where articles about Miyuan dealing with postcolonial issues touch up on indigenous questions. Another brief mention is found in the colonial school debate (see 5.1.1.), when one commentator mentions that aborigines would be even more discriminated than the Taiwanese, and sent off to separate schools. In another piece, a passage describes the main protagonist as having mixed eyes, half-Dutch, half-indigenous which, the critic notes, "is not without importance ${ }^{51 "}$ ". Sometimes alluded to, but never fully developed or analyzed, it constitutes in that sense, a good reflection of the early postcolonial debates in Taiwanese literary circles and academia, which were mainly concerned with the Chinese vs. Taiwanese divide, and in which scrutiny towards indigenous people and indigenous literature would not develop until later. Of course, early exceptions can be found, such as the September 1992 issue of Wenxue Taiwan (issue n4), which articulated discussions of Taiwan nativization, of the White Terror, and of the needed plurality of literature with a special issue on indigenous literature.

\section{Conclusion}

Miyuan and the debate on postcoloniality were undoubtedly products of the late 1980s. Both were enabled by the lifting of the martial law in 1987 (Li Ang needed to travel to Suzhou for the writing of the book ${ }^{52}$ ), earlier debates related to nativist literature, the beginnings of Taiwan-centered literary histories ${ }^{53}$ and more generally, the "Taiwanese cultural nationalist movement [that] upheld Taiwanese culture, challenging China-centered ideology and cultural politics ${ }^{54 \%}$. Practically speaking, the reception of Miyuan raised questions regarding the education and status of Taiwanese children under the Japanese and KMT school systems, embodied coloniality and haircuts of school-age children, the use of the Japanese language and Japanese-era dates in the novel, and botany as a metaphor for transplanted identities. (De)colonization processes, as they related to Holland, Spain, and Taiwan aborigines, were briefly touched upon but did not become fully thematized yet.

\footnotetext{
51 Jin Hengjie 1992, p.132.

52 See Li Ang (李昂), Prof. Jin, you’re wrong - replying to Jin Hengjie’s appraisal of Miyuan (Jin jiaoshou, nin cuo le, hui Jin Hengjie jiaoshou tan Miyuan 金教授，您錯了--回金恒杰教授談《迷園》)，Dangdai, nº72, April 1992 , p. 144.

${ }^{53}$ Ye Shitao（葉石濤）, An Outline of Taiwan Literary History (Taiwan wenxue shigang 臺灣文學史綱), Gaoxiong: Wenxuejie zazhi she, 1987.

${ }^{54}$ Liou 2015, p. 260
} 
As such, the reception of the novel allows us to perform an act of translation - not in the linguistic, but in the mathematical sense - an act of displacement, by five years, of the scholarly literature on Miyuan. Shifting the focus away from 1947-1987, from contexts of production (228 literature, enabled by the lifting of martial law), we can move towards reception, towards 1952-1992: the treaty of Taipei equated to Shimonoseki, as a bridge to thinking the colonial period, and Miyuan as one spark to the larger "1992 debate" on postcolonial literature and to the wealth of articles and literary works that would follow suit. Of course, Miynan is only one of so many novels dealing with reimaginings of the Japanese legacy, the 1950s, or the colonial heritage at large. Across genres, from Kan Yao-ming’s (甘耀明) To Kill Ghosts (Sha Gui 殺鬼) to Li Lung-chieh’s (李隆杰) graphic novel Koxinga $Z$ which won the Golden Comic Awards this October - contemporary literature is not done exhausting its possibilities, and demonstrating its vitality in the $21^{\text {st }}$ century. 